\title{
Diabetic female rats exhibit defensive aggression during mating
}

\author{
Abigail Hernández-Munive, ' Daniela Rebolledo-Solleiro, ${ }^{2}$ Alonso Fernández-Guasti’
}

\begin{abstract}
Laboratorio de Farmacología Conductual. Centro de Investigación y de Estudios Avanzados del Instituto Politécnico Nacional.

2 Laboratorio de Neurobiología Conductual. Departamento de Fisiología, Facultad de Medicina. Universidad Nacional Autónoma de México.
\end{abstract}

\section{Correspondence:}

Alonso Fernández-Guasti

Laboratorio de Farmacología Conductual. Centro de Investigación

y de Estudios Avanzados del Instituto

Politécnico Nacional.

Calzada de los Tenorios 235,

Col. Granjas Coapa,

Alcaldía Tlalpan

14330, Ciudad de México.México.

Phone: +52 $555483-2848$

Email: ffernand@cinvestav.mx

Received: 2 August 2019

Accepted: 11 November 2019

Citation:

Hernández-Munive, A., RebolledoSolleiro, D., \& Fernández-Guasti, A. (2019). Diabetic female rats exhibit defensive aggression during mating Salud Mental, 43(1), 27-33.

DOI: $10.17711 /$ SM.0185-3325.2020.005

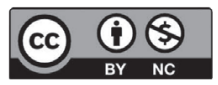

\begin{abstract}
Introduction. Few reports have analyzed the putative association between diabetes mellitus type 1 (DM1) and aggressiveness. A previous study using a model of DM1 reported an increase in aggressive behaviors $(A B)$ of females against the male during mating, which was prevented by insulin. However, it was unclear if such aggression was defensive or offensive. Objective. To evaluate the different components of aggressiveness of hyperglycemic female rats in two distinct mating paradigms. Method. DM1 was modeled in OVX Wistar rats by injecting streptozotocin (STZ) diluted in citrate buffer (50 mg/kg, i.p., for 2 consecutive days). Ten days later, female rats were treated with estradiol benzoate (10 microg, -24 hours) and progesterone ( $3 \mathrm{mg},-4$ hours). A group of STZ-treated animals was administered with a long-acting insulin analogue (glargine) every 12 hours for 8 days. Aggression was recorded in non-paced mating (NPM) and paced mating (PM) paradigms. We registered: the first attack latency ( $F A L)$, the proportion of females that presented $A B$ and its type (boxing, bites, lateral kicks and twist) and if $A B$ were exhibited defensively or offensively. Results. Hyperglycemic rats showed an increase in lateral kicks in NPM, whereas in PM they exhibited an increase in bites. These behaviors were always defensive and there were no changes in FAL. Insulin reduced AB. Discussion and conclusion. Data indicate that the aggressiveness of hyperglycemic female rats is a form of defense against the proximity of the male and add information about the role of insulin on their modulation.
\end{abstract}

Keywords: Aggression, diabetes, insulin, female, rat.

\section{RESUMEN}

Introducción. Pocos trabajos han evaluado la relación entre diabetes mellitus tipo 1 (DM1) y la agresividad. En un estudio se reportó un aumento en las conductas agresivas (CA) de las hembras contra el macho durante la cópula, las cuales se reducen administrando insulina. No está claro si estas CA se expresan de manera defensiva u ofensiva. Objetivo. Evaluar diferentes componentes de la agresividad de ratas hembras hiperglucémicas en dos paradigmas de cópula. Método. La DM1 fue modelada en ratas Wistar ovariectomizadas inyectando estreptozotocina (STZ) disuelta en buffer de citratos $(50 \mathrm{mg} / \mathrm{kg}$, i.p., durante dos días consecutivos). Diez días después, se les administró benzoato de estradiol (10 microg, - 24 horas) y progesterona (3 mg, - 4 horas). A un grupo tratado con STZ se le administró un análogo de insulina (glargina) cada 12 horas durante ocho días. La agresión se registró en los paradigmas de cópula no regulada (NPM) y regulada (PM). Se registraron: la latencia al primer ataque (LPA), la proporción de hembras que exhibieron alguna CA, el tipo (boxeo, mordidas, patadas laterales y giros) y si se presentaron de manera defensiva u ofensiva. Resultados. Las hembras diabéticas mostraron un aumento en las patadas laterales en NPM mientras que en PM exhibieron más mordidas. Las conductas fueron defensivas, no hubo cambios en la LPA. La insulina redujo la expresión de CA. Discusión y conclusión. Los datos indican que las CA de las hembras hiperglucémicas son una forma de defensa contra la proximidad del macho y agregan información sobre el papel de la insulina en su modulación.

Palabras clave: Agresividad, diabetes, insulina, rata, hembra. 


\section{INTRODUCTION}

Diabetes mellitus (DM) is a metabolic disease that has been associated with a large number of comorbidities, such as neuropathies, cardiovascular diseases, and psychosocial problems, being depression the most frequent (Roy \& Lloyd, 2012). It is not surprising that other behaviors could be affected by the homeostatic imbalance caused by DM, because the brain (like the rest of the body) is dependent on glucose and a failure in its control influences its functioning (Andrade, Benton, Brain, Ramirez, \& Walmsley, 1988). Many patients with DM report psychiatric symptoms, such as hyperactivity, unpredictable behavior, internalizing symptoms, and solitary tendencies (van Son et al., 2013). Particularly, diabetic women experience more distress, lower selfesteem, and more depressive symptoms than men (Forsander, Bogelund, Haas, \& Samuelsson, 2017; Hood et al., 2006; Lašaitė et al., 2016; Lašaite, Ostrauskas, Zalinkevicius, Jurgeviciene, \& Radzeviciene, 2015). Aggressiveness is another important concomitant symptom of DM; however, few studies have systematically analyzed their relationship. In these studies, it has been reported that there is an association between glycosylated hemoglobin and aggression (Leonard, Jang, Savik, Plumbo, \& Christensen, 2002). Accordingly, patients with DM1 exhibit higher verbal aggression compared with patients suffering from other chronic diseases (Tilov, Semerdzhieva, Bakova, Tornyova, \& Stoyanov, 2016) or with the general population (Efe \& Erdem, 2018). Nevertheless, these studies have not analyzed the data according to the sex of the patient.

Natural aggression has been considered as an adaptive behavior commonly displayed with different purposes. Firstly, it can be expressed to obtain a benefit (food, sexual partners, or territory) (Trainor, Sisk, \& Nelson, 2009). Secondly, it might be exhibited as a form of defense (a response to a previous stimulation, without inflicting intentional damage) (in rats, this form of aggression is characterized by side kicks and small bites towards the flanks). Finally, it can be executed offensively, i.e., intended to cause injury to the opponent (in the rat offensive aggression consists in boxing posture or bites towards vulnerable body parts) (Adams, 1979; Umukoro, Aladeokin, \& Eduviere, 2013). Notably, exaggerated levels of aggression -quantitatively characterized by short latencies to the first attack and high frequency and duration of attacks- are considered pathological (Takahashi \& Miczek, 2013). The study of aggression in preclinical studies has been done primarily in males because females exhibit less aggressiveness (Cordero, Ansermet, \& Sandi, 2013). These studies have been intended to determine the motivation underlying each aggressive behavior and the neutrotransmitters and brain areas involved in their control.

Preclinical studies of DM (using streptozotocin [STZ], a cytotoxic of pancreatic $\beta$ cells, that generates hyperglyce- mia and hypoinsulinemia) have shown that diabetic animals also exhibit various behavioral changes as observed in humans, such as anxious- and depressive-like behaviors and a decrease in sexual behavior (Can, Ozturk, \& Ozkay, 2011; ElBatsh, 2015; Sahin, Gocmez, Eraldemir, \& Utkan, 2019; Várkonyi \& Kempler, 2014). Few studies have evaluated the relationship between hyperglycemia and aggressiveness in animal models. They have used the intruder-resident paradigm (IRP), and their results have been controversial. Thus, the groups of Meehan (1987) and Leedom (1987) reported that male mice treated with STZ had lower aggression and investigation when placed with another male. Moreover, they presented more static defense postures and escapes (Leedom, Meehan, \& Zeidler, 1987; Meehan, Leedom, Nagayama, \& Zeidler, 1987). Four years later, in another work, it was reported that males administered with STZ showed a tendency to spend less time interacting socially with the resident and more time expressing aggressive behaviors (Hilakivi-Clarke, 1991).

To the best of our knowledge, in females there is only a single work reporting increased aggressiveness in STZ-treated rats tested in two distinct mating conditions (Hernandez-Munive, Rebolledo-Solleiro, Ventura-Aquino, \& Fernandez-Guasti, 2018). In that study, we showed that in the non-paced mating paradigm (NPM), which implies that the timing of copulation is imposed by the male (resulting in some rejection behaviors by the females) (Hardy \& DeBold, 1972), the hyperglycemic females displayed high levels of aggression, which were diminished after insulin administration (Hernandez-Munive et al., 2018). When evaluated in the paced mating paradigm (PM), where the number of aggressive behaviors in control animals is minimal because the female controls the timing of copulation by moving away from the male (Paredes \& Vazquez, 1999), the aggressiveness of hyperglycemic females also tended to increase (Hernandez-Munive et al., 2018). In that report, however, we failed to analyze the features of the aggressive behaviors. Thus, the present study was aimed at establishing whether aggressiveness towards the male was offensive or defensive.

\section{METHOD}

\section{Design of the study}

Quantitative, preclinical study.

\section{Subjects}

In this study, we used 46 ovariectomized (OVX) females $(250-300 \mathrm{~g})$ and 15 sexually experienced male Wistar rats. All animals were housed under standard conditions $\left(22 \pm 2{ }^{\circ} \mathrm{C}\right.$, reversed 12 -hour light and 12-hour dark cy- 
cle, starting the dark phase at 10:00 a.m.) and provided with food and water ad libitum.

\section{Measurements}

\section{a) Behavioral test}

We registered aggression in two different mating paradigms:

1. Where the male regulates sexual interaction in the non-paced mating condition (NPM). In this test, the animals were placed in a transparent circular arena (52 $\mathrm{cm}$ in diameter X $45 \mathrm{~cm}$ high). The test was carried out during the first 10 mounts (approximately 15 minutes).

2. Where the female controls the rhythm of copulation, a paradigm called "paced mating" (PM). This test was performed in a transparent acrylic box (61 $\mathrm{cm}$ long X $30.5 \mathrm{~cm}$ wide X $45 \mathrm{~cm}$ high) divided in two compartments. The division between compartments had two holes $(4.0 \mathrm{~cm})$ in each bottom corner, through which the female, but not the male rat, could freely pass from one compartment to the other. In this test, the evaluation time was longer $(1 \mathrm{~h})$ because a greater number of mounts and intromissions are necessary to establish the pacing behavior.

To induce sexual receptivity, females were administered with estradiol benzoate (10 micrograms per rat, subcutaneously, 24 hours before the test; Sigma Chemicals, St. Louis, MA.) followed by progesterone (3 $\mathrm{mg}$ per rat, subcutaneously, 4 hours before the test; Sigma Chemicals, St. Louis, MA.). Animals were habituated to each paradigm for 5 minutes before introducing the sexually experienced male.

\section{b) Aggressive behavior}

For both paradigms, the latency for the first attack (time -in seconds- between the introduction of the male into the experimental arena to the first aggressive behavior), the number of aggressive females (reported as the proportion of females showing aggression), and the number of aggressive events were recorded. The behaviors considered as aggressive were the following:

- Boxing: the female stands on her two hind legs and pushes the male with the front legs.

- Bites: small bites towards the male from the front or the side, without damaging it.

- Lateral offensive posture kicking the male with hind legs.

- Twist: the female turns half of her body towards the male (Gonzalez, Vaziri, \& Wilson, 1996; Madlafousek \& Hliň́k, 1977).

Furthermore, we determined if these behaviors were displayed offensively, -i.e., if they occurred without a prior stimulus-, or defensively, -if they were the response to a male's approach-.

\section{Procedures}

a) STZ-Treatment

To generate hyperglycemia, OVX-females (surgery performed one week before administration) received STZ (Sigma Chemicals, St. Louis, MA) on two consecutive days $(50 \mathrm{mg} / \mathrm{kg} /$ day, ip.) using citrate buffer (sodium citrate dehydrate and citric acid monohydrate $.1 \mathrm{~mol} / \mathrm{L}, \mathrm{pH} 4.8$ ) as vehicle. Behavioral tests were performed ten days after the last administration. At the end of the behavioral tests, plasma glucose levels were determined using a glucometer and glucose strips (Accu-Chek Performa, Roche, Buenos Aires, Argentina).

\section{b) Insulin treatment}

The insulin treatment consisted in the daily subcutaneous administration of insulin, glargine (Cronix, PiSA Laboratories, Guadalajara, Mexico) in a 12-12 h scheme. Two days after the last STZ administration, $2 \mathrm{U}$ of insulin were administered in the morning and $4 \mathrm{U}$ in the night (for 6 days). To avoid hypoglycemia, the last 2 days of treatment, the dose was lowered to $2 \mathrm{U}$ in the morning and $2 \mathrm{U}$ in the night. Only the females that at the end of the test showed blood glucose levels between 70-100 mg/dL were included.

Our data are the results of two different experimental trials, in which 5 animals of each group were evaluated. Efforts were taken to have the same experimental conditions in each trial in order to assure reproducibility.

\section{Statiscal analysis}

The data were analyzed using the GraphPad 6.0 software; results are presented as the mean \pm the standard error of the mean (SEM). Glucose values and aggressiveness data were analyzed using the MannWhitney U-test because the data failed to follow a normal distribution. Proportions of females that exhibited aggressive behaviors were analyzed with the Fisher`s exact test.

\section{Ethical considerations}

All procedures were done in accordance with the guidelines of the Laws and Codes of Mexico (Norma Oficial Mexicana NOM-062-ZOO-1999. Especificaciones técnicas para la producción, cuidado y uso de los animales de laboratorio) following the guidelines of the National Institutes of Health for the use of animals. The Institutional Ethics Committee (Cicual-CINVESTAV) approved the protocols.

\section{RESULTS}

Control animals showed normal glucose levels $(103 \pm 4$ $\mathrm{mg} / \mathrm{dL}$ ) while STZ-treated animals had hyperglycemia 

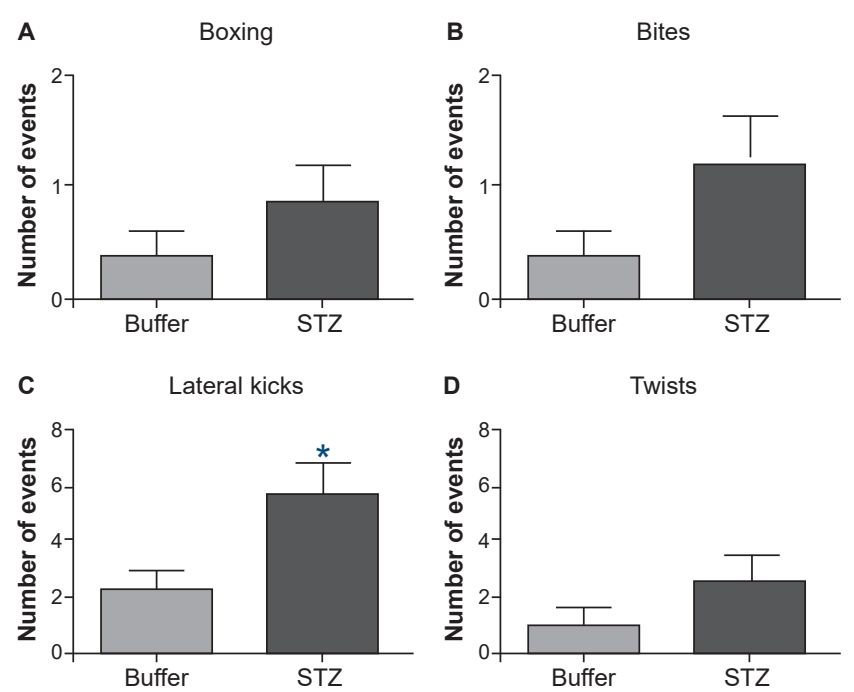

Figure 1. Aggressive behaviors: boxing (panel A), bites (panel $B$ ), lateral kicks (panel C) and twists (panel D) in NPM (Buffer $n=10$, STZ $n=10$ ). ${ }^{*} p<.05$ by Mann-Whitney U-test. STZ: streptozotocin.

$\left(492 \pm 19^{* * *} \mathrm{mg} / \mathrm{dL}[\mathrm{U}=0, * * * p<.0001]\right)$. Figure 1 shows the different aggressive behaviors (boxing posture [panel A], bites [panel B] lateral kicks [panel C] and twists [panel D]) displayed by females treated with buffer $(n=10)$ or STZ $(n=10)$ in a mating condition where they cannot regulate the timing of copulation (NPM). The control females displayed some aggressive behavior during mating; however hyperglycemic females showed more aggressions, reflected as a significant increase in the number of lateral kicks $(\mathrm{U}=21, p=.026)$.

Figure 2 shows the same aggressive behaviors as those shown in figure 1 , but in females tested under PM, where they regulate the time of sexual interaction. In this paradigm, the number of aggressive events was also increased in hyperglycemic females; particularly, there was a significant increase in the number of bites $(\mathrm{U}=22, p=.042)$.

As shown in Table 1, all females treated with STZ presented at least one aggressive response in both paradigms; however, only in PM, where the female can escape to the neutral compartment, the proportion of females showing ag-
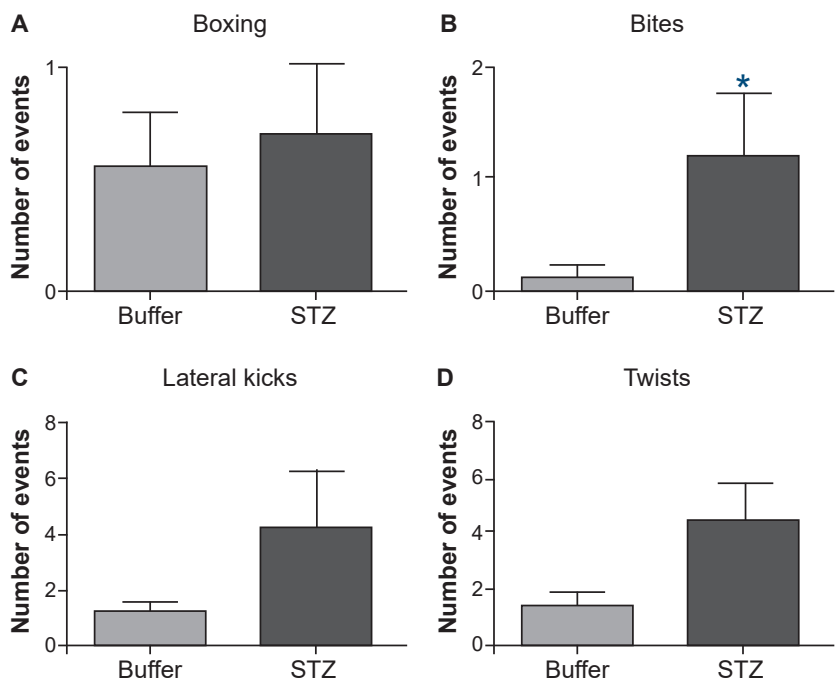

Figure 2. Aggressive behaviors: boxing (panel A), bites (panel B), lateral kicks (panel C) and twists (panel D) in PM (Buffer $n=9$, STZ $n=10)$. ${ }^{*} p<.05$ by Mann-Whitney U-test. STZ: streptozotocin.

gression was significantly increased ( $p=.02$, Fisher's exact test). Moreover, all aggressive behaviors were performed defensively, i.e., in response to a male approach. There were no significant differences in the latency to the first attack between normoglycemic and hyperglycemic females ( $p=$ ns). Finally, the mean number of attacks was increased in hyperglycemic females, such increase reach statistical significance only in the NPM condition and therefore only in this group insulin was administered to explore a possible blockade action.

Interestingly, insulin treatment administered to hyperglycemic females tested in NPM reduced the mean number of attacks $(4 \pm 2)$ to control values ( $p=.02$, Mann -Whitney U-test) as well as the proportion of animals administered with STZ that showed aggression (4/7) ( $p=.05$, Fisher's exact test). Furthermore, the aggressive events executed by these females were scarce, defensive and were displayed with a similar latency $(92 \pm 31)$ than those of the other groups.

Table 1

Proportion of females that presented aggressive behaviors, type of each response (defensive or offensive), latency to the first attack and the mean number of attacks presented in NPM and PM by vehicle- or STZ-treated females

\begin{tabular}{lcccccccc}
\hline & \multicolumn{2}{c}{$\begin{array}{c}\text { Proportion of females } \\
\text { showing aggression }\end{array}$} & \multicolumn{2}{c}{ Type of response } & Latency to the first attack (s) & Mean number of attacks \\
\hline & NPM & $P M$ & NPM & $P M$ & NPM & $P M$ & NPM & $P M$ \\
\hline Buffer & $7 / 10$ & $4 / 9$ & Defensive & & $56 \pm 29$ & $236 \pm 68$ & $3 \pm 1$ & $3 \pm 1$ \\
STZ & $10 / 10$ & $10 / 10^{\wedge}$ & Defensive & & $52 \pm 9$ & $272 \pm 106$ & $9 \pm 2^{*}$ & $11 \pm 2$ \\
\hline
\end{tabular}

Note: NPM = non-paced mating paradigm; PM = paced mating paradigm; STZ = streptozotocin. ${ }^{\wedge} p<.05$ vs. buffer by Fisher`s exact test, ${ }^{*} p<.02$ vs. buffer by Mann-Whitney U-test. 


\section{DISCUSSION AND CONCLUSION}

The main findings of the present study were that the STZ-treated animals exhibited aggressiveness (mostly side kicks and bites) only when the male attempted to mount the female. Remarkably, insulin treatment reverted such increased aggressive behaviors.

As aforementioned, when the female does not regulate the rhythm of sexual interaction (NPM), there is an increased aggression towards the male intended to control the pattern of stimulation that she receives (Paredes \& Vazquez, 1999). In STZ-treated females, the number of these behaviors were much greater than the ones exhibited by controls. Additionally, all these responses were defensive, i.e., they were displayed as a reaction to an approach of the male. The detailed analysis of each aggressive behavior allows to infere about the underlying motivation. Adams (1979) pointed out that the lateral bites or kicks (as the ones exhibited by STZ-treated females in both mating paradigms) are deployed to a part of the body (flanks of the opponent) less vulnerable to serious damage. This observation suggests that hyperglycemic females try to reject the male without hurting him.

It is well known that the main motivation behind the enforcement of aggressive defensive behaviors is the pain or threat posed to another organism (Umukoro et al., 2013). Under this premise, we can suppose that in the case of STZ-treated females, the male represents an aversive stimulus. In support of this idea, it has been evidenced that these animals exhibit fibrosis in the vaginal tissue (Kim et al., 2006; Park et al., 2001) and neuropathy (Banafshe et al., 2014; Gao \& Zheng, 2014; Tripathi, Mehta, \& Yadav, 2016), which are accompanied by inflammatory reactions characterized by inflitration of macrophages and T-cells (Chakrabarty, Liao, Mu, \& Smith, 2018). These factors might produce nociception in the female's rump when mounted.

Another possible explanation for the execution of aggressive defensive behaviors is that the male provokes anxious-like responses in hyperglycemic females. Accordingly, it has been reported that these females have high levels of experimental anxiety (Aksu et al., 2012), and that in postpartum females the kicks against an intruder male are anxious or fearful responses (da Veiga, Miczek, Lucion, \& de Almeida, 2011). This interpretation agrees with what occurs in clinics where women with DM1 have more symptoms of internalization (anxiety, depression) (Kakleas, Kandyla, Karayianni, \& Karavanaki, 2009; Naar-King et al., 2005; Tilov et al., 2016).

An interesting finding of this work is that the increased aggression produced by hyperglycemia was counteracted by insulin treatment. Naturally, peripheral insulin crosses the blood-brain barrier via a saturable transport process Kleinridders, Ferris, Cai, \& Kahn, 2014) and, after prolonged periods of hypoinsulinemia, this transport is reduced, decreasing the amount of insulin in the brain (Banks, Owen, \& Erickson, 2012; Šerbedžija \& Ishii, 2012). Binding of insulin to its receptor in the rodent brain is greater in areas related to cognitive and emotional functions such as: hippocampus, hypotalamus, amygdala, cortex, olfactory bulb, and septum (Craft \& Stennis Watson, 2004); therefore, a decrease in insulin could interfer with the correct function of these areas. For example, it has been demonstrated that an insulin failure leads to an abnormal aminoacids metabolism, which could cause a decrease in the brain serotonin production (Korczak, Pereira, Koulajian, Matejcek, \& Giacca, 2011), a neurotransmitter widely studied in the deployment of aggressiveness (Umukoro et al., 2013). In females treated with STZ, a decrease in the hypothalamic serotonin precursor (tryptophan) has been found since the first week with hyperglycemia (Chaouloff et al., 1989). In addition, it has been shown that insulin has an antidepressant-like effect in mice (Hilakivi-Clarke, 1991), probably due to the increase in serotonin levels (Gupta, Kurhe, \& Radhakrishnan, 2014; Manjarrez-Gutierrez, Herrera-Marquez, Bueno-Santoyo, González-Ramírez, \& Hernández, 2000), making possible to propose that insulin decreases aggressiveness by increasing the activity of this neurotransmitter system.

It is worth mentioning that our results show acute effects of hyperglycemia on the expression of aggressive behaviors. However, in the clinical setting (where the effects are chronic) there is scarce information about the association between glycemic control and aggression. Uncontrolled blood sugar in patients suffering DM1 leads to substantial psychological distress, negative moods, irritable, or aggressive behavior, and closely associated problems with relationships, self-image, and confidence (Vanstone, Rewegan, Brundisini, Dejean, \& Giacomini, 2015). Accordingly, some studies have evidenced a direct relationship between poor glycemic control and a rise in aggressive behaviors (Bryden et al., 2001; Leonard et al., 2002; Zheng $\&$ Chen, 2013). Interestingly, it has been reported that for every $1 \mathrm{mmol} / \mathrm{L}$ rise in glucose levels, there is a concomitant rise of 1.7 in externalizing behavior score (McDonnell, Northam, Donath, Werther, \& Cameron, 2007). Nevertheless, other authors failed to found this association (Akbaş et al., 2009). Remarkably, it has been demonstrated that intranasal administration of insulin reduces anger in healthy subjects (Benedict et al., 2004), without knowing its effects in diabetic patients. Thus, more studies are necessary to clarify the role of insulin in the modulation of aggressive behaviors.

In conclusion, the present work gives evidence that the increased aggressiveness of hyperglycemic females is a form of defense against the proximity of the male and that insulin reverts such aggression. Further studies to clarify the mechanisms underlying this association are warranted. 


\section{Funding}

This work was supported by the Consejo Nacional de Ciencia y Tecnología (CONACyT) grants 420383 and 487669 (to Abigail Hernández-Munive) and grant SEP-CINVESTAV $n^{\circ} 109$. We are thankful with Dirección General de Asuntos del Personal Académico (DGAPA) from the Universidad Nacional Autónoma de México (UNAM) for the grant given to Daniela Rebolledo-Solleiro (2017-2019) during her postdoctoral fellowship.

\section{Conflict of interest}

The authors declare they have no conflicts of interest.

\section{Acknowledgements}

The authors are indebted to Blanca Gómez, MSc. Rebeca Reyes, Ing. José Rodolfo Fernández, and Víctor Manuel Mendoza Salas for their technical support.

\section{REFERENCES}

Adams, D. B. (1979). Brain mechanisms for offense, defense, and submission. Behavioral and Brain Sciences, 2(2), 201-213. doi: 10.1017/ S0140525X00061926

Akbaş, S., Karabekiroğlu, K., Ŏzgen, T., Tasdemir, G., Karakurt, M., Şenses, A., ... Aydin, M. (2009). Association between emotional and behavioral problems and metabolic control in children and adolescents with Type 1 diabetes. Journal of Endocrinological Investigation, 32(4), 325-329. doi: 10.1007/BF03345721

Aksu, I., Ates, M., Baykara, B., Kiray, M., Sisman, A. R., Buyuk, E., ... Uysal, N. (2012). Anxiety correlates to decreased blood and prefrontal cortex IGF-1 levels in streptozotocin induced diabetes. Neuroscience Letters, 531(2), 176-181. doi: 10.1016/j.neulet.2012.10.045

Andrade, M. L., Benton, D., Brain, P. F., Ramirez, J. M., \& Walmsley, S. V. (1988). A reexamination of the hypoglycemia aggression hypothesis in laboratory mice. International Journal of Neuroscience, 41(3-4), 179-186. doi: 10.3109/00207458808990724

Banafshe, H. R., Hamidi, G. A., Noureddini, M., Mirhashemi, S. M., Mokhtari, R., \& Shoferpour, M. (2014). Effect of curcumin on diabetic peripheral neuropathic pain: possible involvement of opioid system. European Journal of Pharmacology, 723, 202-206. doi: 10.1016/j.ejphar.2013.11.033

Banks, W. A., Owen, J. B., \& Erickson, M. A. (2012). Insulin in the brain: there and back again. Pharmacology \& Therapeutics, 136(1), 82-93. doi: 10.1016/j. pharmthera.2012.07.006

Benedict, C., Hallschmid, M., Hatke, A., Schultes, B., Fehm, H. L., Born, J., \& Kern, W. (2004). Intranasal insulin improves memory in humans. Psychoneuroendocrinology, 29(10), 1326-1334. doi: 10.1016/j.psyneuen.2004.04.003

Bryden, K. S., Peveler, R. C., Stein, A., Neil, A., Mayou, R. A., \& Dunger, D. B. (2001). Clinical and psychological course of diabetes from adolescence to young adulthood: a longitudinal cohort study. Diabetes Care, 24(9), 1536-1540. doi: 10.2337/diacare.24.9.1536

Can, O. D., Ozturk, Y., \& Ozkay, U. D. (2011). Effects of insulin and St. John's Wort treatments on anxiety, locomotory activity, depression, and active learning parameters of streptozotocin-diabetic rats. Planta Medica, 77(18), 1970-1976. doi: 10.1055/s-0031-1280129

Cordero, M. I., Ansermet, F., \& Sandi, C. (2013). Long-term programming of enhanced aggression by peripuberty stress in female rats. Psychoneuroendocrinology, 38(11), 2758-2769. doi: 10.1016/j.psyneuen.2013.07.005

Craft, S., \& Stennis Watson, G. S. (2004). Insulin and neurodegenerative disease: shared and specific mechanisms. The Lancet Neurology, 3(3), 169-178. doi: 10.1016/s1474-4422(04)00681-7

Chakrabarty, A., Liao, Z., Mu, Y., \& Smith, P. G. (2018). Inflammatory reninangiotensin system disruption attenuates sensory hyperinnervation and mechanical hypersensitivity in a rat model of provoked vestibulodynia. The Journal of Pain, 19(3), 264-277. doi: 10.1016/j.jpain.2017.10.006
Chaouloff, F., Laude, D., Mérino, D., Serrurier, B., Baudrie, V., \& Elghozi, J. L (1989). Duration of streptozotocin diabetes influences the response of hypothalamic serotonin metabolism to immobilization stress. Neuroendocrinology, 50(3), 344-350. doi: 10.1159/000125244

da Veiga, C. P., Miczek, K. A., Lucion, A. B., \& de Almeida, R. M. (2011). Social instigation and aggression in postpartum female rats: role of 5-Ht1A and 5-Ht1B receptors in the dorsal raphé nucleus and prefrontal cortex. Psychopharmacology, 213(2-3), 475-487. doi: 10.1007/s00213-010-2083-5

Efe, Y. S., \& Erdem, E. (2018). A comparison of aggression and self-injury among type 1 diabetic and healthy adolescents: a sample from Turkey. Archives of Psychiatric Nursing, 32(2), 174-179. doi: 10.1016/j.apnu.2017.10.012

ElBatsh, M. M. (2015). Antidepressant-like effect of simvastatin in diabetic rats. Canadian Journal of Physiology and Pharmacology, 93(8), 649-656. doi: 10.1139/cjpp-2014-0560

Forsander, G., Bogelund, M., Haas, J., \& Samuelsson, U. (2017). Adolescent life with diabetes-Gender matters for level of distress. Experiences from the national TODS study. Pediatric Diabetes, 18(7), 651-659. doi: 10.1111/pedi.12478

Gao, F., \& Zheng, Z. M. (2014). Animal models of diabetic neuropathic pain. Experimental Clinical Endocrinology \& Diabetes, 122(2), 100-106. doi: 10.1055/s-0033-1363234

Gonzalez, M. I., Vaziri, S., \& Wilson, C. A. (1996). Behavioral effects of $\alpha-M S H$ and $\mathrm{MCH}$ after central administration in the female rat. Peptides, 17(1), 171-177. doi: 10.1016/0196-9781(95)02092-6

Gupta, D., Kurhe, Y., \& Radhakrishnan, M. (2014). Antidepressant effects of insulin in streptozotocin induced diabetic mice: Modulation of brain serotonin system. Physiology \& Behavior, 129, 73-78. doi: 10.1016/j.physbeh.2014.02.036

Hardy, D. F., \& DeBold, J. F. (1972). Effects of coital stimulation upon behavior of the female rat. Journal of Comparative and Physiological Psychology, 78(3), 400-408. doi: 10.1037/h0032536

Hernandez-Munive, A. K., Rebolledo-Solleiro, D., Ventura-Aquino, E., \& FernandezGuasti, A. (2018). Reduced lordosis and enhanced aggression in paced and nonpaced mating in diabetic female rats. The Journal of Sexual Medicine, 15(2), 124-135. doi: 10.1016/j.jsxm.2017.11.018

Hilakivi-Clarke, L. A. (1991). Effects of tryptophan on depression and aggression in STZ-D mice. Diabetes, 40(12), 1598-1602. doi: 10.2337/diab.40.12.1598

Hood, K. K., Huestis, S., Maher, A., Butler, D., Volkening, L., \& Laffel, L. M. (2006). Depressive symptoms in children and adolescents with type 1 diabetes: association with diabetes-specific characteristics. Diabetes Care, 29(6), 13891391. doi: 10.2337/dc06-0087

Kakleas, K., Kandyla, B., Karayianni, C., \& Karavanaki, K. (2009). Psychosocial problems in adolescents with type 1 diabetes mellitus. Diabetes \& Metabolism, 35(5), 339-350. doi: 10.1016/j.diabet.2009.05.002

Kim, N. N., Stankovic, M., Cushman, T. T., Goldstein, I., Munarriz, R., \& Traish, A. M. (2006). Streptozotocin-induced diabetes in the rat is associated with changes in vaginal hemodynamics, morphology and biochemical markers. $B M C$ Physiology, 6(1), 4. doi: 10.1186/1472-6793-6-4

Kleinridders, A., Ferris, H. A., Cai, W., \& Kahn, C. R. (2014). Insulin action in brain regulates systemic metabolism and brain function. Diabetes, 63(7), 2232-2243. doi: $10.2337 / \mathrm{db} 14-0568$

Korczak, D. J., Pereira, S., Koulajian, K., Matejcek, A., \& Giacca, A. (2011). Type 1 diabetes mellitus and major depressive disorder: evidence for a biological link. Diabetologia, 54(10), 2483-2493. doi: 10.1007/s00125-011-2240-3

Lašaitè, L., Dobrovolskienè, R., Danytè, E., Stankutė, I., Ražanskaitė-Virbickienė, D., Schwitzgebel, V., ... Verkauskienè, R. (2016). Diabetes distress in males and females with type 1 diabetes in adolescence and emerging adulthood. Journal of Diabetes and its Complications, 30(8), 1500-1505. doi: 10.1016/j. jdiacomp.2016.08.013

Lašaitė, L., Ostrauskas, R., Zalinkevicius, R., Jurgeviciene, N., \& Radzeviciene, L. (2015). Profile of mood states in adult type 1 diabetes mellitus men and women with disease onset in childhood and in adulthood. Journal of Pediatric Endocrinology and Metabolism, 28(3-4), 279-285. doi: 10.1515/jpem-20140162

Leedom, L. J., Meehan, W. P., \& Zeidler, A. (1987). Avoidance responding in mice with diabetes mellitus. Physiology \& Behavior, 40(4), 447-451. doi:10.1016/0031-9384(87)90029-1 
Leonard, B. J., Jang, Y. P., Savik, K., Plumbo, P. M., \& Christensen, R. (2002). Psychosocial factors associated with levels of metabolic control in youth with type 1 diabetes. Journal of Pediatric Nursing, 17(1), 28-37. doi: 10.1053/ jpdn.2002.30931

Madlafousek, J., \& Hliňák, Z. (1977). Sexual behaviour of the female laboratory rat: Inventory, patterning, and measurement. Behaviour, 63(3-4), 129-174. doi: 10.1163/156853977X00397

Manjarrez-Gutierrez, G., Herrera-Marquez, R., Bueno-Santoyo, S., GonzálezRamírez, M., \& Hernández, J. (2000). Changes in brain serotonin biosynthesis in rats with diabetes mellitus induced by streptozocin: effect of insulin treatment. Revista de Investigacion Clinica; organo del Hospital de Enfermedades de la Nutricion, 52(5), 509-516.

McDonnell, C. M., Northam, E. A., Donath, S. M., Werther, G. A., \& Cameron, F. J. (2007). Hyperglycemia and externalizing behavior in children with type 1 diabetes. Diabetes Care, 30(9), 2211-2215. doi: 10.2337/dc07-0328

Meehan, W. P., Leedom, L. J., Nagayama, T., \& Zeidler, A. (1987). Hyperglycemia and fight-flight behavior in nondiabetic and diabetic mice. Physiology \& Behavior, 41(5), 397-403. doi: 10.1016/0031-9384(87)90072-2

Naar-King, S., Idalski, A., Ellis, D., Frey, M., Templin, T., Cunningham, P. B., \& Cakan, N. (2005). Gender differences in adherence and metabolic control in urban youth with poorly controlled type 1 diabetes: the mediating role of mental health symptoms. Journal of Pediatric Psychology, 31(8), 793-802. doi: 10.1093/jpepsy/jsj090

Paredes, R. G., \& Vazquez, B. (1999). What do female rats like about sex? Paced mating. Behavioural Brain Research, 105(1), 117-127. doi: 10.1016/S01664328(99)00087-X

Park, K., Ryu, S. B., Park, Y. I., Ahn, K., Lee, S. N., \& Nam, J. H. (2001). Diabetes mellitus induces vaginal tissue fibrosis by TGF-beta 1 expression in the rat model. Journal of Sex \& Marital Therapy, 27(5), 577-587. doi: 10.1080/713846811

Roy, T., \& Lloyd, C. E. (2012). Epidemiology of depression and diabetes: A systematic review. Journal of Affective Disorders, 142, S8-S21. doi: 10.1016/ s0165-0327(12)70004-6

Sahin, T. D., Gocmez, S. S., Eraldemir, F. C., \& Utkan, T. (2019). Anxiolytic-Like and Antidepressant-Like effects of resveratrol in streptozotocin-induced diabetic rats. Noro Psikiyatr Ars, 56(2), 144-149. doi: 10.29399/npa.23176

Šerbedžija, P., \& Ishii, D. N. (2012). Insulin and insulin-like growth factor prevent brain atrophy and cognitive impairment in diabetic rats. Indian Journal of
Endocrinology and Metabolism, 16(Suppl 3), S601-S610. doi: 10.4103/22308210.105578

Takahashi A., Miczek K.A. (2013) Neurogenetics of Aggressive Behavior: Studies in Rodents. In: Miczek K., Meyer-Lindenberg A. (eds) Neuroscience of Aggression. Current Topics in Behavioral Neurosciences, 17, 3-44. Berlin, Heidelberg: Springer. doi: 10.1007/7854_2013_263

Tilov, B., Semerdzhieva, M., Bakova, D., Tornyova, B., \& Stoyanov, D. (2016). Study of the relationship between aggression and chronic diseases (diabetes and hypertension). Journal of Evaluation in Clinical Practice, 22(3), 421-424. doi: 10.1111/jep. 12502

Trainor, B. C., Sisk, C. L., \& Nelson, R. J. (2009). Hormones and the development and expression of aggressive behavior. In Hormones, Brain and Behavior Online, 2, 167-205. Elsevier, Inc. doi: 10.1016/B978-008088783-8.00005-X

Tripathi, C. D., Mehta, A. K., \& Yadav, A. M. (2016). Drug combinations in diabetic neuropathic pain: an experimental validation. Journal of Basic and Clinical Physiology and Pharmacology, 27(6), 617-624. doi: 10.1515/jbcpp-2015-0163

Umukoro, S., Aladeokin, A. C., \& Eduviere, A. T. (2013). Aggressive behavior: A comprehensive review of its neurochemical mechanisms and management. Aggression and Violent Behavior, 18(2), 195-203. doi: 10.1016/j. avb.2012.11.002

van Son, J., Nyklicek, I., Pop, V. J., Blonk, M. C., Erdtsieck, R. J., Spooren, P. F., ... Pouwer, F. (2013). The effects of a mindfulness-based intervention on emotional distress, quality of life, and $\mathrm{HbA}(1 \mathrm{c})$ in outpatients with diabetes (DiaMind): a randomized controlled trial. Diabetes Care, 36(4), 823-830. doi: 10.2337/dc121477

Vanstone, M., Rewegan, A., Brundisini, F., Dejean, D., \& Giacomini, M. (2015). Patient perspectives on quality of life with uncontrolled type 1 diabetes mellitus: A systematic review and qualitative meta-synthesis. Ontario Health Technology Assessment Series, 15(17), 1-29.

Várkonyi, T., \& Kempler, P. (2014). Sexual dysfunction in diabetes. Handbook of Clinical Neurology, 126, 223-232. doi: 10.1016/B978-0-444-53480-4.00017-5

Zheng, X. P., \& Chen, S. H. (2013). Psycho-behavioral changes in children with type 1 diabetes mellitus. World Journal of Pediatrics, 9(3), 261-265. doi: 10.1007/ s12519-013-0428-y 